\title{
Moderator Effect of Corporate Governance on the Relationship of Financial Performance and Dividend Policy, and Its Impact on Firm Value in Indonesia Stock Exchange
}

Djayani Nurdin* and Muhammad Yunus Kasim

Fakultas Ekonomi, Universitas Tadulako, Indonesia

\begin{abstract}
This study focused on the investigation of moderating corporate governance and financial performance in relation dividend policy and its impact on the firm value in Indonesia Stock Exchange. This study used a survey with an explanatory approach method Moderated Regression Analysis (MRA) and 2 SLS with panel data. The method of estimation uses the Generalized Least Squares (GLS). This study uses secondary data manufacturing companies listed in Indonesia Stock Exchange, for the period of observation from 2006 until 2015. This study resulted in five empirical findings. First, a significant effect on the financial performance of dividend policy, second, corporate governance generally cannot moderate the relationship of financial performance and development policy dividends. Third, the financial performance of a significant effect on firm value, Fourth, corporate governance generally cannot moderate the relationship the firm value and the company's financial performance. Fifth, the dividend policy has no significant effect on firm value. Sixth, dividend policy cannot mediate the relationship financial performance with the firm value.
\end{abstract}

Keywords: Financial performance; Corporate governance; Dividend policy; Firm value

\section{Introduction}

\section{Research background}

Until the last three months of 2015, large and medium manufacturing industries had positive work performance in which in October and November, both recorded $10,04 \%$ and $0,01 \%$ for its performances. However, in November 2015 the industries went downfall and had a weakening of $3.26 \%$. In the midst of development of the manufacturing sector, BPS noted that there are many industries that experienced production decline from January to December 2015.

The issue of corporate governance revived its popularity after few of corporations in U.S such as Goldman Sachs, Bear Stern, Morgan Stanley, Merrill Lynch and Lehman Brothers collapsed. The phenomenon reminded about the beginning of the rise of corporate governance. As the U.S is one of the countries that have high index of CGPI (Corporate Governance Perception Index), it raises question on to what extent is the role of corporate governance in supporting the corporations' objectives.

Corporate governance can be used as moderation variable in a research on the relationship between financial performance with dividend policy and the firm value because the firm will be able to maximize its value when it pays attention to its stakeholders or investors. The balance in the achievement of stakeholders' objectives creates opportunity to gain optimal profit and in return the firm's performance will be valued well by the investors.

The well implementation and management of corporate governance or known as good corporate governance is a concept that emphasizes on the importance of the rights of the investors to acquire information correctly, accurately and on time. It also shows the responsibility of the firm to disclose all the information regarding financial performance accurately, transparent and on time. Therefore, both the public firm and private firm must see good corporate governance (CGC) not only as accessories but also as an effort to increase the firm's value. Based on the empirical gap phenomena and the theoretical gap explained above, the researcher is interested in conducting a research entitled "Moderator Effect of Corporate Governance on the Relationship between Financial Performance and Dividend Policy, and Its Impact on Firm Value in Indonesia Stock Exchange"

\section{Literature Review}

There are many researches that explain the negative consequences of weak governance system and attempted to identify the determinant factors that may increase the implementation of corporate governance. Iskander and Chamlou [1], Alijoyo et al. [2] stated that the economic crisis in Southeast Asia and other countries occurred not only due to macroeconomic factor but also due to the weak corporate governance in those countries such as weak laws, weak accounting standards and auditing, under-regulated stock exchange market, weak supervision of commissioners and neglected minority rights.

The measurement of corporate governance practice in the firm level led to many studies that managed to find positive relationship between corporate governance and firm value [3-5]. These studies indirectly showed the usefulness of corporate governance practice in firm level that has been practiced in many countries including Indonesia.

According Berghe and Ridder in their research, to see the relationship between good governance and firm value is not easy. Many previous researches showed that there is no relationship between corporate governance and firm value such as the research of Daily

*Corresponding author: Djayani Nurdin, Fakultas Ekonomi, Universitas Tadulako Indonesia, Tel: 62451 422611; E-mail: dj_nurdin@yeshoo.com

Received November 03, 2017; Accepted December 04, 2017; Published December 08, 2017

Citation: Nurdin D, Kasim MY (2017) Moderator Effect of Corporate Governance on the Relationship of Financial Performance and Dividend Policy, and Its Impact on Firm Value in Indonesia Stock Exchange. Int J Econ Manag Sci 7: 499. doi: 10.4172/2162-6359.1000499

Copyright: $\odot 2017$ Nurdin D, et al. This is an open-access article distributed under the terms of the Creative Commons Attribution License, which permits unrestricted use, distribution, and reproduction in any medium, provided the original author and source are credited. 
Citation: Nurdin D, Kasim MY (2017) Moderator Effect of Corporate Governance on the Relationship of Financial Performance and Dividend Policy, and Its Impact on Firm Value in Indonesia Stock Exchange. Int J Econ Manag Sci 7: 499. doi: 10.4172/2162-6359.1000499

and Dalton [6]. The same result was also acquired by Young [7] that analyzed few researches that link corporate governance with firm value.

Klein [8] found that the independent board of directors is more effective in conducting supervision. This was also stated by Cornett et al. [9] where the firm value will increase with the increase of independent commissioners.

Meanwhile Chen et al. [10] also found that the characteristic of independent board, number of meetings and length of service of board have relations with the level of fraud in a firm. Liu and $\mathrm{Hu}$ [11] stated that board structure not only serves as control mechanism in the making of finance report but also as controlling shareholder in conducting activities that are disadvantage to the investors.

Lipton and Lorsch [12], Jensen [13], Beiner et al. [14] are the ones that concluded that commissioner board are part of corporate governance mechanism. This was backed up by the opinions of Allen and Gale [15] that stated that commissioner board is a part of an important governance mechanism.

The researches on the impact of independent commissioner to firm value are still varied in its results. There are researches that stated the high proportion of independent board have positive relationship with the firm performance [16-18], and is not included as the factor to firm performance [19], and have negative relationship with the performance $[20,21]$.

The influence of the size of the commissioner board to the firm value also has variety of result. The more personnel that become commissioner board can impact to the worsening of firm performance [22].

Other few researchers found that the size of the board have significant negative influence to the profit management. The lesser personnel of the board means the higher fraud because the less number of the board personnel creates possibility for that $[23,24]$.

Regarding the size of director board, several researchers found different results. Eisenberg et al. stated that there are negative relations between the size of the board and the firm performance. While Dalton et al. stated that there are positive relations between the size of the board and the firm value.

According to Kakabadse et al. [25] the difference result of the researches are caused by few things: 1) theoretical perspectives implemented 2) research methodology 3) performance measurement, and 4) different view on the involvement of the board in decision making. Although these researches on the relationship of corporate governance and firm value showed different results, all showed that corporate governance have direct and indirect influence to the firm value.

The major contribution of a research that studies the relationship between corporate governance and firm value was from Yermack [16], Gompers et al. [26] Cremers et al. [27] and Bebchuk et al. [28]. In these researches, it was concluded that good structure of corporate governance impacts to better performance and increased firm value.

An early study by Baysinger and Hoskinson [29] examined the relationship between percentage of independent commissioner board and firm value. They found that firms with much independent external board are better than firms without. Baysinger and Hoskinson also concluded that the board that consists of the combination of external and internal people from the firm creates the best firm value.
Yermack [16], Bhagat and Black [30], Agrawal and Knoeber [31] found negative correlation between Tobin Q and the proportion of independent board. Bhagat and Black found the relations between the firm values in the market with independent commissioner board. Rosenstein and Wyestt [32] used event study methodology and found small increase of stock price when the firm uses independent board.

\section{Research Purpose}

The research purpose is to study on:

1) The capacity of finance performance in achieving dividend policy

2) How corporate governance moderate the relationship between financial performance with dividend policy

3) How financial performance may impact to firm value

4) How corporate governance moderate the relationship between financial performance and firm value

5) The capacity of dividend policy in achieving firm value

6) The capacity of dividend policy in mediating the relationship between financial performance and firm value.

\section{Research Methodology}

\section{Methodology}

In accordance with the intent and purpose of research as previously stated, the method used in this research is the Explanatory Survey method. This study by its nature is included in descriptive and verificative research [33].

\section{Variable operationalization}

Operationalization of variables aims to explain the measurement of various variables and research indicators that are used in this research. They are as follows as shown in Table 1 .

\section{Population and Sample}

The target population in this study is all manufacturing companies listed on the Indonesia Stock Exchange (BEI), with observation period from 2006 to 2015. From the data acquired from Indonesia Stock Exchange, the number of manufacturing firms from December 2015 is 184 issuers.

The sampling method used in this research is purposive sampling. Purposive method is sampling method in which the researcher has particular criteria and purpose to the samples studied. Based on the data acquired from ICMD from 206 to 2015, there are only 92 firms that are recorded in Indonesia Stock Exchange.

\section{Analysis design and hypothesis testing}

Hypothesis testing on the dividend policy model and firm value is conducted by estimating the following equation:

Dividend_ $1_{\mathrm{it}}=\mathrm{a}_{0}+\mathrm{a}_{1} \mathrm{ROE}_{\mathrm{it}}+\mathrm{a}_{2} \mathrm{CR}_{\mathrm{it}}+\mathrm{a}_{3} \mathrm{DER}_{\mathrm{it}}+\mathrm{a}_{4} \log (\text { Sale })_{\mathrm{it}}+\mathrm{a}_{5} \mathrm{FAge}_{\mathrm{it}}+\varepsilon_{\text {lit }}(1)$

Dividend_2 $2_{\mathrm{it}}=\mathrm{b}_{0}+\mathrm{b}_{1} \mathrm{ROE}_{\mathrm{it}}+\mathrm{b}_{2} \mathrm{KIND}_{\mathrm{it}}+\mathrm{b}_{3} \mathrm{DIR}_{\mathrm{it}+} \mathrm{b}_{4} \mathrm{TT}_{\mathrm{it}}+\mathrm{b}_{5} \mathrm{ROE}_{\mathrm{it}}{ }^{*} \mathrm{KIN}$ $\mathrm{D}_{\mathrm{it}}+\mathrm{b}_{6} \mathrm{ROE}_{\mathrm{it}}{ }^{*} \mathrm{DIR}_{\mathrm{it}}+\mathrm{b}_{7} \mathrm{ROE}_{\mathrm{it}}{ }^{*} \mathrm{TT}_{\mathrm{it}}+\varepsilon_{2 \mathrm{it}}$

Dividend_ $3_{\text {it }}=\mathrm{c}_{0}+\mathrm{c}_{1} \mathrm{CR}_{\mathrm{it}}+\mathrm{c}_{2} \mathrm{KIND}_{\mathrm{it}}+\mathrm{c}_{3} \mathrm{DIR}_{\mathrm{it}+} \mathrm{c}_{4} \mathrm{TT}_{\mathrm{it}}+\mathrm{c}_{5} \mathrm{CR}_{\mathrm{it}}{ }^{*} \mathrm{KIND}_{\mathrm{it}}+\mathrm{c}_{6} \mathrm{C}$ $\mathrm{R}_{\mathrm{it}}^{*} \mathrm{DIR}_{\mathrm{it}}+\mathrm{c}_{7} \mathrm{CR}_{\mathrm{it}} \mathrm{TT}_{\mathrm{it}}+\varepsilon_{3 \mathrm{it}}$ 
Citation: Nurdin D, Kasim MY (2017) Moderator Effect of Corporate Governance on the Relationship of Financial Performance and Dividend Policy, and Its Impact on Firm Value in Indonesia Stock Exchange. Int J Econ Manag Sci 7: 499. doi: 10.4172/2162-6359.1000499

Page 3 of 7

\begin{tabular}{|c|c|c|c|c|}
\hline \multicolumn{2}{|l|}{ Variable } & \multirow{2}{*}{$\begin{array}{l}\text { Dimension } \\
\text { Tobins Ratio (TBNSQ) }\end{array}$} & \multirow[b]{2}{*}{$\begin{array}{l}\text { Indicator } \\
\text { TBNSQ=(MVE+DEBT)/TA } \\
\text { MVE=Market Value of Equity } \\
\text { TA=Total Assets } \\
\text { DEBT=(Current Liabilities -Current Assets)+Inventories } \\
\text { +Non-Current Liabilities. }\end{array}$} & \multirow{2}{*}{$\begin{array}{l}\text { Scale } \\
\text { Ratio }\end{array}$} \\
\hline Endogen & Firm Value (FV) & & & \\
\hline \multirow[t]{3}{*}{ Eksogen } & \multirow[t]{3}{*}{$\begin{array}{l}\text { Financial Performance } \\
\text { (KK) }\end{array}$} & Profitability: Return on Equity (ROE) & $\begin{array}{l}\text { ROE=EAT/Total Equity } \\
\text { EAT=Earnings After Tax }\end{array}$ & Ratio \\
\hline & & Liquidity: Cash Ratio (CR) & $\mathrm{CR}=$ Cash+Cash equivalent/Current Liabilities & Ratio \\
\hline & & $\begin{array}{l}\text { Solvency: Debt to Equity Ratio } \\
\text { (DER) }\end{array}$ & DER=Total debt/Total Equity & Ratio \\
\hline Mediation & Dividend Policy (DP) & Dividend Payout Ratio (DPR) & $\begin{array}{l}D P R=D P S / E P S \\
\text { DPS=Dividend Per Share } \\
\text { EPS=Earnings Per Share }\end{array}$ & Ratio \\
\hline \multirow[t]{3}{*}{ Moderating } & \multirow[t]{3}{*}{$\begin{array}{l}\text { Corporate Governance } \\
\text { (CG) }\end{array}$} & $\begin{array}{l}\text { Composition of Independent } \\
\text { Commissioners (KIND) }\end{array}$ & $\begin{array}{l}\text { Percentage of board members of independent } \\
\text { commissioners out of total number of commissioner board }\end{array}$ & Ratio \\
\hline & & Directors Board Size (DIR) & Number of members of the board of directors & Ratio \\
\hline & & Duality (TT) & $\begin{array}{l}\text { Temporary member of directors board out of the total } \\
\text { number of members of director board }\end{array}$ & Ratio \\
\hline \multirow[t]{3}{*}{ Control } & Firm size & Total Asset (TA) & Total Asset Logarithm & Ratio \\
\hline & Sale & Sale (Sale) & Log $($ Sale $)=$ Price $\times$ Quantity & Ratio \\
\hline & Firm Age & Listing (Fage) & Fage=Observation year - Listing year & Ratio \\
\hline
\end{tabular}

Table 1: Operational definition and research variable measurement.

\begin{tabular}{|c|c|c|c|c|c|c|}
\hline Sample & Minimum & Maximum & Mean & $\begin{array}{c}\text { Standard deviation } \\
(n-1)\end{array}$ & Skewness (Pearson) & Kurtosis (Pearson) \\
\hline ROE & $(0,3249)$ & 0,5763 & 0,1202 & 0,2232 & 0,109 & 0,011 \\
\hline CR & 0,0003 & 10462 & 0,3052 & 0,3572 & 1179 & $-0,101$ \\
\hline DER & -19199 & 39815 & 13435 & 14521 & 0,320 & $-0,121$ \\
\hline KIND & 0,1000 & 0,5450 & 0,3796 & 0,0826 & 0,357 & $-0,525$ \\
\hline DIR & 20000 & 90000 & 48130 & 19149 & 0,835 & $-0,385$ \\
\hline TT & 0,0000 & 0,8000 & 0,2081 & 0,2585 & 1049 & $-0,032$ \\
\hline TA (Juta) & 13.173 & 182.374 .000 & 4.225 .641 & 12.676 .756 & 74147 & 752336 \\
\hline Sale (Juta) & 1 & 188.053 .000 & 4.226 .884 & 12.678 .358 & 82818 & 918905 \\
\hline FAGE (Thn) & 2 & 35 & 154228 & 53597 & 0,251 & 0,160 \\
\hline DPR & 0,0000 & 0,5783 & 0,1116 & 0,1744 & 1282 & 0,203 \\
\hline FV & $(0,3123)$ & 19867 & 0,9352 & 0,5913 & 0,555 & $-0,713$ \\
\hline
\end{tabular}

Source: Result of data processing.

Table 2: Descriptive statistic of research variable.

Dividend_ $4_{\mathrm{it}}=\mathrm{d}_{0}+\mathrm{d}_{1} \mathrm{DER}_{\mathrm{it}}+\mathrm{d}_{2} \mathrm{KIND}_{\mathrm{it}}+\mathrm{d}_{3} \mathrm{DIR}_{\mathrm{it}} \mathrm{d}_{4} \mathrm{TT}_{\mathrm{it}}+\mathrm{d}_{5} \mathrm{DER}_{\mathrm{it}}{ }^{\star} \mathrm{KIN}$ $\mathrm{D}_{\mathrm{it}}+\mathrm{d}_{6} \mathrm{DER}_{\mathrm{it}}{ }^{*} \mathrm{DIR}_{\mathrm{it}}+\mathrm{d}_{7} \mathrm{DER}_{\mathrm{it}}{ }^{*} \mathrm{TT}_{\mathrm{it}}+\varepsilon_{4 \mathrm{it}}$

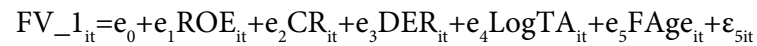

$\mathrm{FV} \_2_{\mathrm{it}}=\mathrm{f}_{0}+\mathrm{f}_{1} \mathrm{ROE}_{\mathrm{it}}+\mathrm{f}_{2} \mathrm{KIND}_{\mathrm{it}}+\mathrm{f}_{3} \mathrm{DIR}_{\mathrm{it}} \mathrm{f}_{4} \mathrm{TT}_{\mathrm{it}}+\mathrm{f}_{5} \mathrm{ROE}_{\mathrm{it}}{ }^{*} \mathrm{KIND}_{\mathrm{it}}+\mathrm{f}_{6} \mathrm{ROE}$ ${ }_{\text {it }}^{*} \mathrm{DIR}_{\text {it }}+\mathrm{f}_{7} \mathrm{ROE}_{\text {it }}{ }^{*} \mathrm{TT}_{\text {it }}+\varepsilon_{\text {6it }}$

$\mathrm{FV} \_3_{\mathrm{it}}=\mathrm{g}_{0}+\mathrm{g}_{1} \mathrm{CR}_{\mathrm{it}}+\mathrm{g}_{2} \mathrm{KIND}_{\mathrm{it}}+\mathrm{g}_{3} \mathrm{DIR}_{\mathrm{it}} \mathrm{g}_{4} \mathrm{TT}_{\mathrm{it}}+\mathrm{g}_{5} \mathrm{CR}_{\mathrm{it}}{ }^{*} \mathrm{KIND}_{\mathrm{it}}+\mathrm{g}_{6} \mathrm{CR}_{\mathrm{it}}{ }^{\star}$ $\mathrm{DIR}_{\mathrm{it}}+\mathrm{g}_{7} \mathrm{CR}_{\mathrm{it}}{ }^{*} \mathrm{TT}_{\mathrm{it}}+\varepsilon_{7 \mathrm{it}}$

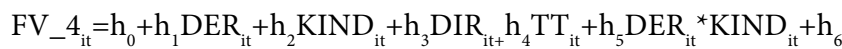
$\mathrm{DER}_{\mathrm{it}}{ }^{*} \mathrm{DIRL}_{\mathrm{it}}+\mathrm{h}_{7} \mathrm{DER}_{\mathrm{it}}{ }^{*} \mathrm{TT}_{\mathrm{it}}+\varepsilon_{8 \mathrm{it}}$

$$
\text { FV_ } 5_{\text {it }}=\mathrm{i}_{0}+\mathrm{i}_{1} \text { Dividend }_{\text {it }}+\mathrm{i}_{2} \log (\mathrm{TA})_{\mathrm{it}}+\mathrm{i}_{3} \mathrm{FAGE}+\varepsilon_{9 \mathrm{it}}
$$

$F V \_\sigma_{\text {it }}=\mathrm{p}_{0}+\mathrm{p}_{1}$ Pred_DPR $\mathrm{itt}_{11 \mathrm{it}}$

\section{Research Result and Discussion}

\section{Research variable description}

Descriptive statistic is a data description of each variable by using 92 firm samples for 10 years from 2006 to 2015 just as showed in Table 2 below.
The descriptive statistic result above shows that there are four indicators where the average value is above the deviation standard which is KIND, DIR, FAge and FV whereas seven other indicators have bigger deviation standard value than the average.

\section{Hausman test}

The test used to determine whether to use Fixed Effect Model or Random Effect Model is Hausman test. The result of the Hausman test is shown in the Table 3 below:

The test result showed that there are 8 equation models that use fixed Effect Model, the result is based on the significant value (p-value) of dividend policy model that is less than 0,05 . Meanwhile there is 1 equation model that uses Random Effect Model which is estimation 2c and 6 models.

\section{Test of dividend policy and firm value hypothesis}

The empirical model of the estimation result of dividend policy on manufacturing industries recorded in Indonesia Stock Exchange can be seen in the Table 4 below:

Because $\mathrm{F}_{\text {hitung }}>\mathrm{F}_{\text {tabel }}(2.2236)$ and $\mathrm{p}$-value $<\alpha=0,05$, it can be inferred 
Citation: Nurdin D, Kasim MY (2017) Moderator Effect of Corporate Governance on the Relationship of Financial Performance and Dividend Policy, and Its Impact on Firm Value in Indonesia Stock Exchange. Int J Econ Manag Sci 7: 499. doi: 10.4172/2162-6359.1000499

Page 4 of 7

\begin{tabular}{|c|c|c|c|c|c|}
\hline & No & Model & $X^{2}$-hitung & p-value & Keterangan \\
\hline \multirow[t]{4}{*}{ Dividend } & 1 & Estimation 1 & 255262 & 0,0001 & Fixed Effect \\
\hline & 2 & Estimation 2.a & 242463 & 0,0010 & Fixed Effect \\
\hline & 3 & Estimation 2.b & 186684 & 0,0093 & Fixed Effect \\
\hline & 4 & Estimation 2.c & 111033 & 0,1342 & Random Effect \\
\hline \multirow[t]{6}{*}{ Firm Value } & 5 & Estimation 3 & 354678 & 0,0000 & Fixed Effect \\
\hline & 6 & Estimation 4.a & 194751 & 0,0068 & Fixed Effect \\
\hline & 7 & Estimation 4.b & 234212 & 0,0014 & Fixed Effect \\
\hline & 8 & Estimation 4.c & 210335 & 0,0037 & Fixed Effect \\
\hline & 9 & Estimation 5 & 189592 & 0,0003 & Fixed Effect \\
\hline & 10 & Estimation 6 & 0,8921 & 0,3349 & Random Effect \\
\hline
\end{tabular}

Source: Data processing result.

Table 3: Test result of the use of fixed effect or random effect dividend policy model and firm value.

\begin{tabular}{|c|c|c|c|c|c|c|}
\hline \multirow[t]{2}{*}{ Variable } & \multirow[t]{2}{*}{ Expected sign } & \multicolumn{4}{|c|}{ Equation } & \multirow[t]{2}{*}{ Hypothesis Support } \\
\hline & & 1 & $2 a$ & $2 b$ & 2c & \\
\hline Constant & & $0,1097^{\star}$ & $0,3739^{*}$ & $0,3777^{\star}$ & $-0,0576$ & \\
\hline ROE & $(+)$ & $0,0018^{* *}$ & $-0,0218$ & & & Yes and no \\
\hline CR & $(+)$ & $0,3529^{*}$ & & $-0,0003$ & & \\
\hline DER & $(-)$ & $-0,0046^{*}$ & & & 0,0463 & \\
\hline KIND & $(+)$ & & $0,0397^{* *}$ & $0,0212^{\star}$ & $0,6423^{*}$ & Yes and no \\
\hline DIR & $(+)$ & & $-0,0007$ & $-0,0005$ & $0,0669^{*}$ & \\
\hline $\mathrm{TT}$ & $(-)$ & & $-0,0206$ & $-0,0090^{*}$ & $-0,2482^{* *}$ & \\
\hline ROE $\times$ KIND & $(+)$ & & 0,0371 & & & Yes and no \\
\hline ROE × DIR & $(+)$ & & $0,0068^{*}$ & & & \\
\hline ROE $\times$ TT & $(-)$ & & $-0,0124^{* * *}$ & & & \\
\hline $\mathrm{CR} \times \mathrm{KIND}$ & $(+)$ & & & $-0,0071$ & & No \\
\hline$C R \times D I R$ & $(+)$ & & & 0,0011 & & \\
\hline $\mathrm{CR} \times \mathrm{TT}$ & $(-)$ & & & 0,0057 & & \\
\hline DER $\times$ KIND & $(+)$ & & & & $-0,0553$ & Yes and no \\
\hline DER × DIR & $(+)$ & & & & $-0,0163^{*}$ & \\
\hline $\mathrm{DER} \times \mathrm{TT}$ & $(-)$ & & & & 0,0065 & \\
\hline Log (Sale) & $(+)$ & $0,0170^{*}$ & & & & Yes \\
\hline Fage & $(+)$ & $0,0022^{*}$ & & & & \\
\hline F-stat & & 1990443 & 1246306 & 3681772 & 69497 & Yes \\
\hline Adjusted $\mathrm{R}^{2}$ & & 0,9539 & 0,9925 & 0,9974 & 0,0433 & \\
\hline
\end{tabular}

Keterangan: ROE is profitability; CR is liquidity; DER is solvency; KIND is independent commissioners; DIR is the number of directors; TT is duality; Log (Sale) issale; Fage is listing year.

*Statistically supported in alpha $1 \%$

"Statistically supported in alpha $5 \%$,

${ }^{* *}$ Statistically supported in alpha $10 \%$.

Table 4: Test result of dividend policy hypothesis.

that exogenous variable in the model can describe the linear relationship with endogen variable or in other words, the exogenous collectively have significant influence to the dividend value in manufacturing industry listed in Indonesia's Stock Exchange (BEI).

The empirical model of estimation result of company value model at manufacturing industry listed on BEI can be seen in Table 5 as follows:

Information: ROE is profitability; CR is liquidity; DER is solvency; KIND is independent commissioners DIR is the number of directors; TT is duality; DPR is dividend policy; Pred_DPR: Predicted dividend policy; $\log (\mathrm{TA})$ is the size of the firm; Fage is listing age.

Since Fcount $>$ Ftable (2.2236) and $p$-value $<\alpha=0.05$, it can be concluded that the exogenous variable involved in the model can describe the linear relationship with the endogenous variable or in other words the five exogenous variables collectively have a significant effect on firm value on manufacturing industry is listed on BEI.

\section{Research discussion}

Dividend policy discussion: The results of this study make it clear that larger companies and the ability to perform financial performances are more likely to pay dividends, as firms with large investment opportunities are less likely to pay dividends. These results are in line with the results of De Angelo and De Angelo [34], Pruitt and Gitman [35], De Angelo and Skinner [36], Baker and Powell, Fama and French [37], Al-Malkawi [38].

The results of this study indicate that independent commissioners as one of the proxies of internal corporate governance structure are less effective in fighting for shareholder rights in the form of dividend payout by the company. The results of this study do not support the findings of Kowalewski, et al. [39] yang presenting that dividend payouts determined by independent commissioners as one of the strengths of internal corporate governance.

The number of directors is able to moderate the performance 


\begin{tabular}{|c|c|c|c|c|c|c|c|c|}
\hline \multirow{2}{*}{ Variable } & \multirow{2}{*}{ Exp } & \multicolumn{6}{|c|}{ Equation } & \multirow{2}{*}{$\begin{array}{l}\text { Supported by } \\
\text { Hypothesis }\end{array}$} \\
\hline & & 3 & $4 a$ & $4 b$ & 4c & 5 & 6 & \\
\hline Constant & & $1,5851^{*}$ & $0,7739^{\star}$ & $0,7947^{*}$ & $0,6103^{*}$ & $1,7368^{*}$ & $0,7011^{*}$ & Yes \\
\hline ROE & $(+)$ & $0,0063^{* *}$ & $-0,1016$ & & & & & Yes and no \\
\hline CR & $(+)$ & $0,0635^{* *}$ & & $-0,5028^{*}$ & & & & \\
\hline DER & $(-)$ & $-0,0176^{\star}$ & & & $0,0618^{* *}$ & & & \\
\hline KIND & $(+)$ & & $0,2610^{* *}$ & 0,0789 & $0,4624^{*}$ & & & Yes and no \\
\hline DIR & $(+)$ & & $-0,0194^{* * *}$ & $-0,0073^{*}$ & 0,0054 & & & \\
\hline TT & $(-)$ & & $0,6464^{*}$ & $0,8606^{*}$ & $0,7440^{*}$ & & & \\
\hline ROE $\times$ KIND & $(+)$ & & 0,2425 & & & & & Yes and No \\
\hline $\mathrm{ROE} \times \mathrm{DIR}$ & $(+)$ & & $0,0371^{* *}$ & & & & & \\
\hline $\mathrm{ROE} \times \mathrm{TT}$ & $(-)$ & & $-0,1655^{\star \star *}$ & & & & & \\
\hline $\mathrm{CR} \times \mathrm{KIND}$ & $(+)$ & & & $0,5829^{*}$ & & & & Yes \\
\hline$C R \times D I R$ & $(+)$ & & & $0,0283^{*}$ & & & & \\
\hline $\mathrm{CR} \times \mathrm{TT}$ & $(-)$ & & & $0,1543^{*}$ & & & & \\
\hline DER $\times$ KIND & $(+)$ & & & & $-0,1016$ & & & No \\
\hline $\mathrm{DER} \times \mathrm{DIR}$ & $(+)$ & & & & $-0,0119$ & & & \\
\hline $\mathrm{DER} \times \mathrm{TT}$ & $(-)$ & & & & 0,0524 & & & \\
\hline DPR & $(+)$ & & & & & 0,0277 & & No \\
\hline PRED_DPR & $(+)$ & & & & & & $0,6084^{*}$ & Yes \\
\hline $\log (T A)$ & $(+)$ & $0,0575^{*}$ & & & & $0,0730^{*}$ & & Yes \\
\hline Fage & $(+)$ & $0,0115^{\star}$ & & & & $0,0126^{*}$ & & \\
\hline F-stat & & 1817311 & 3802910 & 1015,18 & 6004324 & 305819 & 180084 & Yes \\
\hline Adjusted $\mathrm{R}^{2}$ & & 0,9496 & 0,9758 & 0,9908 & 0,9845 & 0,9689 & 0,2528 & \\
\hline
\end{tabular}

Keterangan: ROE is profitability; CR is liquidity; DER is solvency; KIND is independent commissioners; DIR is the number of directors; TT is duality; Log (Sale) issale; Fage is listing year.

*Statistically supported in alpha $1 \%$

**Statistically supported in alpha $5 \%$,

*** Statistically supported in alpha $10 \%$.

Table 5: Hypothesis firm value testing result.

relationship with dividend policy. The implication of this research is that the bigger the board of directors the better the company's financial performance in influencing the dividend policy. This means that the addition of one person to the board of directors can lead to effective and efficient decision-making in a company. This study is in accordance with directors positively influence the relationship between financial performances with dividend policy.

In general it can be argued that the duality of the board's role in a manufacturing company can moderate the relationship between financial performance and dividend policy, whereas ideal if there is a duality of roles, the degree of dividend policy will be higher, this is because they can run multiple roles, as supervisors and simultaneously as the executor.

Firm value discussion: The results of this study explain that larger companies and have the ability of financial performance is more likely to value the company, while companies with poor financial performance conditions is less likely to increase the value of the company.

The proportion of independent board of commissioners has no significant effect on the value of the company. The explanation can be given that the addition of independent board members is possible only to meet formal requirements, while majority shareholders (controllers/ founders) still play an important role so that the performance of the board does not increase.

Other results also explain that the addition of one person to the board of directors can lead to effective and efficient decision-making within a company. Because, with many members on the board of directors impact on the number of thoughts and suggestions provided so it will be able to provide meaningful input. This study contradicts Yermack's research [16]; Eisenberg, et al. [22]; Alonso, Palenzuela and Iturriaga stating that directors negatively affect the value of the company.

The results of this study also explain that duality cannot moderate the relationship between financial performances with firm value. These results differ from Saleh et al. research [40] indicates that companies in which there is a duality of role has a positive effect on earnings management. While Klein found that directors with powers exceeding the board of commissioners have the potential to manipulate earnings easily.

In line with the theory put forward by Miller and Modigliani who argue that dividend policy does not affect the value of the company because according to them dividend payout ratio is only the details and no affect the welfare of shareholders [41].

This shows that the company's dividend policy cannot mediate the relationship between financial performance and firm value. The result of earnings regression coefficient, liquidity and solvency in previous equation model 3, yields significant coefficients. The existence of dividend policy no can improve the ability of financial performance to increase the value of the company in the eyes of investors [42-46].

\section{Conclusion and Recommendations}

This study yields six conclusions, as follows: 1) High profitability and liquidity can improve the company dividend policy; on the other hand low solvency can improve the company dividend policy. 2) Financial Performance can improve the policy of dividend in the company that enhances the role of director. Conversely, financial 
Citation: Nurdin D, Kasim MY (2017) Moderator Effect of Corporate Governance on the Relationship of Financial Performance and Dividend Policy, and Its Impact on Firm Value in Indonesia Stock Exchange. Int J Econ Manag Sci 7: 499. doi: 10.4172/2162-6359.1000499

Page 6 of 7

performance can't improve dividend-sharing policies in companies that increase the number of independent and dual commissioners. 3) High profitability and liquidity can increase the value of the company; otherwise low solvency can increase company value. 4) Financial performance can increase the value of a company to a company that enhances the director's role. Conversely, financial performance can't increase the value of the company in the company that increases the number of independent and dual commissioners. 5) A large dividend payout policy can't increase the value of the company. 6) Variable financial performance can't increase the value of the company, through improvement of corporate dividend policy.

Academic Suggestions are; 1) to researchers who will conduct research relevant to this research to include macroeconomic variables in addition to fundamental variables. 2) Subsequent research divides the manufacturing sector into three categories namely basic chemical industry, various industries and consumer goods industry. Practical suggestions are: 1) Investors in taking investment decisions to assess the prospects of future value of the company in addition to consideration of corporate profits

\section{Acknowledgements}

The success of this research may not be separated from the help, guidance, and encouragement from various parties. On this occasion the authors conveyed their gratitude as much as possible to: (1) Prof. Dr. H. Sucherly, SE, MS, (2) Erie Febrian, SE, MBA, M.Comm, Ph.D., (3) Dr. Rachmat Sudarsono SE. MS. as dissertation promoters. In addition, the author also expressed his gratitude to the family and friends who have been helped to complete this research.

\section{References}

1. Iskander MR, Chamlou N (2000) Corporate Governance: A Framework for Implementation. The World Bank, Washington DC.

2. Alijoyo A, Elmar B, Nazmudin S, Doddy K (2004) Review of Corporate Governance in Asia: Corporate Governance in Indonesia. Forum for Corporate Governance in Indonesia.

3. Black BS, Khanna V (2007) Can Corporate Governance Reforms Increase Firm Market Values? Event Study Evidence from India. Journal of Empirical Legal Studies 4: 749-796.

4. Klapper, Leora F, Love I (2002) Corporate Governance, Investor Protection and Performance in Emerging Market. World Bank Working Paper.

5. Mitton T (2004) Corporate Governance and Dividen policy in emerging market. Emerging Markets Review 5: 409-426.

6. Daily CM, Dalton DR (1994) Bankruptcy and Corporate Governance: The Impact of Board Composition and Structure. The Academy of Management Journal 37: 1603-1617.

7. Young B (2003) Corporate governance and firm performance: Is there a relationship? Ivey Business Journal. Improving the Practice of Management.

8. Klein A (2002) Audit Committee. Board of Director Characteristics and Earnings Management. Journal of Accounting and Economics 33: 375-400.

9. Cornett MM, Marcuss J, Sounders H, Tehranian (2006) Earnings Management Corporate Governance, and True Financial Performance. Working Paper.

10. Chen CR, Weiyu G, Vivek M (2006) Corporate Value, Manajerial Stockholdings and Invesment of Japanese Firms. Journal of International Financial Management and Accounting 17: 29-51.

11. Liu, Shulian, Yesnhong H (2005) Empirical Analysis of Cash Dividend Payment in Chinese Listed Companies. Nature and Science 3.

12. Lipton M, Lorsh JW (1992) A modest proposed for improved corporate governance. Business Lawyer 48: 59-77.

13. Jensen MC (1993) The Modern Industrial Revolution, Exit, and the Failure of Internal Control System. Journal of Finance 48: 831-880.

14. Beiner S, Drobetz W, Schmid F, Zimmermann H (2003) Is Board size An Independent Corporate Governance Mechanism?
15. Allen F, Gale D (2000) Diversity of Opinion and Financing of New Technologies. Journal of Financial Intermediation 8: 68-89.

16. Yermack D (1996) Higher Market Valuation of Companies with a Small Board of Directors, Journal of Financial Economics 40: 185-211.

17. Dalton DR, Daily CM, Johnson JL, Ellstrand AE (1999) Number of directors and financial performance: A meta-analysis. Academy of Management Journa 42: $674-686$

18. Daily CM (1993) Board of directors leadership and structure: Control and performance implications. Entrepreneurship Theory and Practice, Max M. Fisher College of Business, Ohio State University, USA.

19. Kesner I, Johnson RB (1990) An Investigation of the relationship between board composition and stockholder suits. Strategic Management Journal 11 327-336.

20. Baysinger BD, Kosnik RH, Turk TA (1991) Effects of Board and Ownership Structure on Corporate R\&D Strategy. Academy of Management Journal 34 205-214.

21. Goodstein J, Boeker W (1991) Turbulence at the top: A new perspective on governance structure changes and strategic change. Academy of Management Journal 34: 306-330

22. Eisenberg T, Sundgren S, Wells MT (1998) Larger Board Size and Decreasing Firm Value in Small Firms. Journal of Financial Economics 48: 35-54.

23. Yu $F$ (2009) Analyst coverage and earnings management. Journal of Financia Economics 88: 245-271.

24. Xie, Biao, Wallace N, Peter JD (2003) Earning Management and Corporate Governance: The Roles of The Beard and The Audit Committee. Journal of Corporate Finance 9: 295-316.

25. Kakabadse A, Ward K, Korac-Kakabdse N, Bowman C (2001) Role and Contribution of non-executive directors. Corporate Governance: The International Journal of Business in Society 1: 4-8.

26. Gompers P, Ishii J, Metrick A (2003) Corporate governance and equity prices Quarterly Journal of Economics 118: 107-155.

27. Cremers M, Nair V, Wei C (2007) Governance mechanisms and bond prices Review of Financial Studies 20: 1359-1388.

28. Bebchuk L, Cohen A, Ferrell A (2004) What matters in corporate governance? Working paper. Harvard Law School.

29. Baysinger B, Hoskinsson RE (1990) The composition of the Board of Directors and Strategic Control: Effects of corporate strategy. Academy of Management Review 15: 72-87.

30. Bhagat S, Bernard B (1999) The uncertain relationship between board composition and firm performance. Business Lawyer 54: 921-963.

31. Agrawal A, Knouber CR (1996) Firm Performance and Mechanisme to Control Agency Problem between Managers and Shareholders. Journal of Financial and Quantitative Analysis 31: 377-397.

32. Rosenstein S, Jeffrey GW (1990) Outside directors, board independence, and shareholder wealth. Journal of Financial Economics 26: 175-191.

33. Cooper DR, Emory CW (1996) Business Research Methods (5thedn), Richard D. Irwin, Inc., USA.

34. De Angelo H, DeAngelo L (1990) Dividend policy and financial distress: An empirical investigation of troubled NYSE firms. Journal of Finance 45: 1415 1431.

35. Pruitt Stephen W, Lawrence JG (1991) The Interactions between the Invesment, Financing, and Dividend Decisions of Major U.S. Firm. Financial Review 26: 409-430.

36. De Angelo H, DeAngelo L, Skinner DJ (2002) Are Dividend Disappearing? Dividend Concentration and the Consolidation of Earning. Journal of Finance and Business Economics 72: 425-456.

37. Fama EF, French KR (2001) Disappearing Dividends: Changing Firm Characteristics or Lower Propensity to Pay? Journal of Financial Economics 60: 3-43.

38. Al-Malkawi, Husam-Aldin Nizar (2007) Determinants of Corporate Dividend Policy in Jordan: An Application of the Tobit Model. Journal of Economic \& Administrative Sciences 23: 44-70. 
Citation: Nurdin D, Kasim MY (2017) Moderator Effect of Corporate Governance on the Relationship of Financial Performance and Dividend Policy, and Its Impact on Firm Value in Indonesia Stock Exchange. Int J Econ Manag Sci 7: 499. doi: 10.4172/2162-6359.1000499

39. Kowalewski O, Ivan S, Oleksandr T (2007) Corporate Governance and Dividend Policy in Poland.

40. Saleh TM, Iskandar MM, Rahmat (2005) Earnings management and board characteristics: Evidence from Malaysia. Jurnal Pengurusan 24: 77-103.

41. Boanyah, Ebenezer A, Desmond TA, Osei YF (2013) Determinants of Dividend Payout Policy of Some Selected Manufacturing Firms Listed on The Ghana Stock Exchange. Journal of Finance and Accounting 4: 49-60.

42. Hermalin BE, Weisbach MS (2003) Board of Directors as an Endogenously Determined Institution: Survey of the Economic Literature. FRBNY Economic Policy Review 9: 7-26.
43. Li, Kai, Xinlei Z (2007) Asymmetric Information and Dividend Policy.

44. Andrés A, López I, Rodríguez S (2005) Financial decisions and growth opportunities: A Spanish firm's panel data analysis. Applied Financial Economics 15: 391-407.

45. Benartzi S, Roni M, Richard T (1997) Do Changes in Dividends Signal the Future or the Past. Journal of Finance 52: 1007-1034.

46. Mohamed G, Amel B (2006) On the Determinants and Dynamics of Dividend Policy. International Review of Finance. International Review of Finance Ltd 6: 1-23 